\title{
ETS1 variants confer susceptibility to ankylosing spondylitis in Han Chinese
}

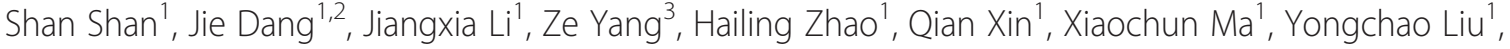 \\ Xianli Bian', Yaogin Gong ${ }^{1}$ and Qiji Liu ${ }^{1 *}$
}

\begin{abstract}
Introduction: ETS1 is a negative regulator of the Th17 differentiation gene and plays a central role in the pathogenesis of autoimmune diseases. We aimed to investigate whether polymorphisms in ETS1 confer susceptibility to ankylosing spondylitis (AS) in Han Chinese.
\end{abstract}

Methods: We selected seven single nucleotide polymorphisms (SNPS) within ETS1 based on HapMap data and previous genome-wide association study. Genotyping involved the TaqMan method in 1,015 patients with AS and 1,132 healthy controls from Shandong Province, and 352 AS patients and 400 healthy controls from Ningxia, a northwest region in China. Gene expression was determined by real-time PCR.

Results: The SNP rs1128334 was strongly associated with AS (odds ratio 1.204, 95\% confidence interval 1.06-1.37; $P=0.005)$. This association was confiexrmed in the Ningxia population $(P=0.015)$. Carriers of the haplotype TAT for rs12574073, rs1128334 and rs4937333 were associated with increased risk of AS and haplotype CGC with reduced risk as compared to controls. In addition, ETS1 expression was lower in AS patients than controls. The risk allele A of rs 1128334 and haplotype A-T of rs 1128334 and rs4937333 were associated with decreased expression of ETS1.

Conclusions: Common variants in ETS1 may contribute to AS susceptibility in Han Chinese people.

\section{Introduction}

Ankylosing spondylitis (AS) is a common inflammatory arthritis that affects the axial skeleton and peripheral joints [1]; it is usually accompanied by lower back pain, peripheral arthritis, enthesis and iritis, and even spinal deformity and ankylosis, ultimately limiting the mobility of the spine and other joints [2]. Genetic factors are strongly implicated in the pathogenesis of the disease, and the estimated heritability is up to $97 \%$ according to a twin study $[3,4]$.

The major histocompatibility complex (MHC), mostly from human leukocyte antigen B27 (HLA-B27), accounts for nearly half of the predisposition for AS [5]. Although HLA-B27 is strongly associated with risk of AS, its associated genes account for only $20 \%$ to $30 \%$ of the overall genetic risk of AS [1]. Thus, other loci may be involved. Besides HLA-B27, non-MHC genes implicated in the risk

\footnotetext{
* Correspondence: liuqiji@sdu.edu.cn

${ }^{1}$ Key Laboratory for Experimental Teratology of the Ministry of Education and Department of Medical Genetics, Shandong University School of Medicine, Jinan, Shandong 250012, China

Full list of author information is available at the end of the article
}

of AS include ERAP1, KIF21B, IL23R and two intergenic regions at chromosome 2p15 and chromosome 21q22 in a European population $[6,7]$.

Two recent genome-wide association studies (GWASs) of an Asian population demonstrated a novel region containing ETS1 at chromosome 11q23 strongly associated with systemic lupus erythematosus (SLE) [8,9]. rs6590330, rs1128334 and rs4937333 were identified as the susceptible variants associated with SLE. Subsequently, many genetic studies reported that rs11221332 of ETS1 is associated with rheumatoid arthritis (RA) and celiac disease, both characterized by excessive activation of the immune system $[10,11]$. Also, increasing evidence has suggested that many of the known AS-associated loci overlap with those of other immune-related diseases. Because of clinical and immunological overlap of AS and other autoimmune diseases [12], ETS1 may be associated with AS as well. In this study, we investigated the association of ETS1 genetic polymorphisms and AS in Han Chinese people.

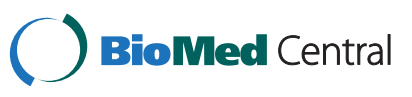

(c) 2014 Shan et al.; licensee BioMed Central Ltd. This is an Open Access article distributed under the terms of the Creative Commons Attribution License (http://creativecommons.org/licenses/by/2.0), which permits unrestricted use, distribution, and reproduction in any medium, provided the original work is properly credited. The Creative Commons Public Domain Dedication waiver (http://creativecommons.org/publicdomain/zero/1.0/) applies to the data made available in this article, unless otherwise stated 


\section{Methods \\ Subjects}

We recruited 2,899 unrelated subjects in this case-control study from 2008 to 2011, including 1,015 patients (701 male, 69.1\%) with AS from Shandong Provincial Hospital and Qilu Hospital in Jinan, Shandong province. All patients, at a mean age of $38 \pm 8.3$ years, had no history of inflammatory bowel disease and/or psoriasis and met the modified New York criteria for AS. We also recruited 1,132 unrelated, randomly sampled healthy controls (603 male, 53.3\%) from a health check-up center at the hospital during the same period; the mean age was $40 \pm 7.2$ years old. All subjects were ethnic Han living in Shandong, an eastern coastal province of North China. More detailed information about the samples was reported previously [13]. The replication samples of 352 AS patients and 400 controls from Ningxia (a province in northwest China) were provided by Professor Yang Ze, with detailed information [14]. Flow cytometry was used to immunophenotype HLA-B27 in patients and controls, and only HLA-B27positive patients and HLA-B27-negative controls were recruited.

Genomic DNA from peripheral blood leukocytes was extracted by a standard phenol-chloroform method. The study was approved by the ethics committee for human studies at the Shandong University School of Medicine, and all subjects provided their informed consent.

\section{Sequence analysis of the human ETS1 gene}

All nine coding exons and 1,000 bp of the $5^{\prime}$ upstream sequence of ETS1 were sequenced in DNA samples from 100 AS cases to screen for genetic variants. ETS1 was amplified by PCR before sequencing. The PCR reaction was run in a total volume of $50 \mu \mathrm{L}$ solution containing $5 \times$ PCR buffer, $10 \mu \mathrm{L} ; 5 \times \mathrm{dNTP}(1 \mathrm{mmol} / \mathrm{L}$ each of dATP, dTTP, dGTP and dCTP), $10 \mu \mathrm{L} ; 50$ ng genomic DNA; 0.4 $\mu \mathrm{M}$ of each primer; and $1 \mathrm{U}$ Taq DNA polymerase. The PCR amplification conditions were optimized with an initial denaturation step at $94^{\circ} \mathrm{C}$ for 5 minutes followed by 35 cycles of $94^{\circ} \mathrm{C}$ for $40 \mathrm{sec}$, optimal annealing temperature for $40 \mathrm{sec}$, extension at $72^{\circ} \mathrm{C}$ for $40 \mathrm{sec}$ and a final extension step of $72^{\circ} \mathrm{C}$ for 10 minutes. All sequencing was performed by the Genomic Analysis Facility (Shenzhen Huada, Shenzhen, China) and analyzed with use of Chromas 2.33 software.

\section{Single nucleotide polymorphism (SNP) selection and genotyping}

Because we were unable to detect novel variants in the sequencing region, we selected seven SNPs (rs12574073, rs1128334, rs4937333, rs4254089, rs7951925, rs7116578 and rs4937342) in ETS1 with minor allele frequency $\geq 0.05$ and $r^{2}>0.8$ in data for Han Chinese in Beijing (HCB) in HapMap [15] and genotyped by TaqMan SNP genotyping assay using assay-on-demand probes and primers (C_31697960_10 for rs12574073, C_7539918_10 for rs1128224, C_278298_10 for rs4937333, C_449693_10 for rs4254089 C_220576_10 for rs7951925, C_29363433_10 for rs7116578, C_27979762_20 for rs4937342; Applied Biosystems, Foster City, CA, USA). rs1128334 and rs4937333 were reported to be strongly associated with SLE and were therefore selected and investigated. We also selected rs12574073 as a candidate SNP because it was a proxy SNP for rs6590330, demonstrated to be associated with SLE in a previous GWAS [9]. The locations of these SNPs are shown in Figure 1. All genotyping involved use of the Lightcycler 480 real-time PCR system (Roche, Mannheim, Germany). The PCR reaction was run in a total volume of $5 \mu \mathrm{L}$ solution containing $2 \times$ Premix EX Taq (Takara, Otsu, Shiga, Japan), $2.5 \mu \mathrm{L} ;>10 \mathrm{ng}$ genomic DNA; $2.5 \mu \mathrm{M}$ of each primer; and $0.05 \mu \mathrm{L}$ probes. The PCR amplification conditions were $95^{\circ} \mathrm{C}$ for $30 \mathrm{sec}, 45 \mathrm{cy}-$ cles of $95^{\circ} \mathrm{C}$ for $5 \mathrm{sec}, 60^{\circ} \mathrm{C}$ for $20 \mathrm{sec}$ and $40^{\circ} \mathrm{C}$ for $30 \mathrm{sec}$ for cooling. Genotyping accuracy in the samples was confirmed by direct sequencing of PCR products for $5 \%$ of randomly chosen samples.

\section{RT-PCR}

Total peripheral leukocyte RNA was extracted from 50 AS patients and 161 healthy controls by the TRIzol reagent method (Invitrogen, Carlsbad, CA, USA), then underwent reverse transcription by use of a reverse transcript kit (Takara, Otsu, Shiga, Japan). Allelic-specific expression of ETS1 was analyzed only in healthy controls. RNA samples were treated with RNase free DNAase to eliminate genomic DNA contamination before being reverse-transcribed into cDNA. Real-time quantitative RT-PCR to amplify cDNA involved the Roche 480 real-time PCR system with SYBR Green Master Mix (Applied Biosystems, Foster City, CA, USA). Relative expression was analyzed by the comparative threshold cycle $(\mathrm{Ct})$ method and normalized to that of human glyceraldehyde-3-phosphate dehydrogenase (GAPDH), calculated by the $2^{-\triangle \Delta \mathrm{Ct}}$ method and $\log ^{10}$ transformed. The primer sequences for ETS1 were sense 5'-TACACAGGCAGTGGACCAATC-3' and antisense 5'-CCCCGCTGTCTTGTGGATG-3'; and GAPDH, sense 5'-CCAGGTGGTCTCCTCTGACTT-3' and antisense 5'-GTTGCTGTAGCCAAATTCGTTGT-3'. Melting curve analysis was used to confirm specificity, with four duplicate wells used for each subject [16].

\section{Statistical analysis}

The SNPs were tested for adherence to Hardy-Weinberg equilibrium (HWE) by chi-square test. Comparison of the allele frequency of the seven SNPs for patients and controls involved Fisher's exact test with use of Plink 1.07 [17]. The Bonferroni correction was used for multiple test correction. Pairwise linkage disequilibrium (LD) was measured 


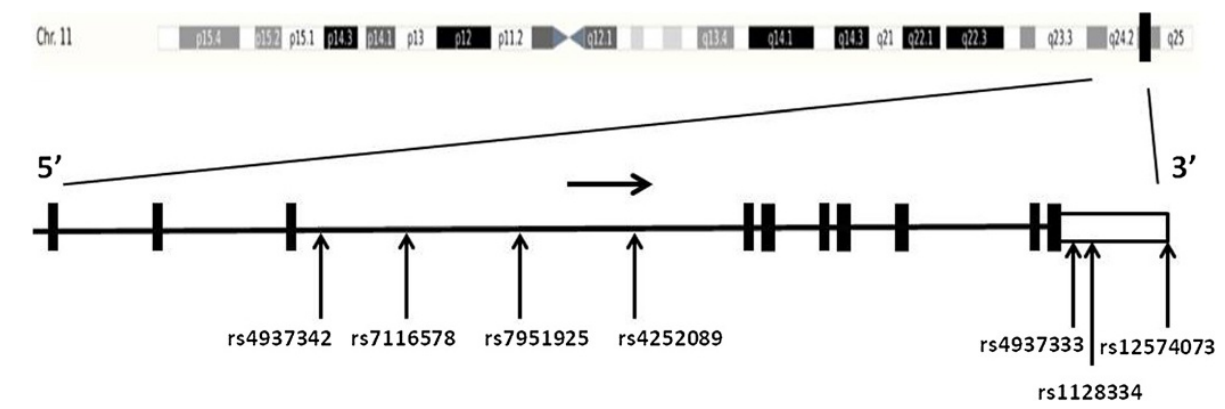

Figure 1 Schematic location of seven single nucleotide polymorphisms (SNPs) in the ETS1 gene.

with use of Haploview 4.2. Three-locus haplotypes were calculated by use of a full precise-iteration algorithm with the online SHEsis software [18]. Differences in allelic expression were tested by $t$-test and analysis of variance (ANOVA) by use of GraphPad Prism v5.01 (GraphPad Software, La Jolla, CA, USA). $P<0.05$ was considered statistically significant.

\section{Results \\ Sequencing}

To search for new variants in the ETS1 gene, we sequenced all exons including the untranslated region (UTR) and 5' upstream regulatory region. However, no novel variant was found in any of the nine exons or $1,000 \mathrm{bp}$ of the upstream sequence.

\section{Association study}

We obtained allele, genotype and haplotype distributions for seven markers in ETS1 in chromosome 11q23 for 1,132 controls and 1,015 patients with AS in Shandong. The allele frequency for each SNP was analyzed (Table 1), and none deviated significantly from HWE, as determined at the 0.05 significance level. Frequency of the rs1128334 allele A was significantly higher in AS patients $(P=0.005$, odds ratio (OR) $1.204,95 \%$ CI 1.06 , 1.37) than in healthy controls. Even after the Bonferroni correction, the association remained significant $\left(P_{C}=\right.$ 0.035). rs12574073 and rs4937333 were associated with AS but not after the Bonferroni correction. Then, we replicated the associated SNP rs1128334 in the Ningxia cohort of 352 cases and 400 matched controls. The minor allele frequency of rs1128334 was greater for cases than controls $(P=0.015$, OR $1.31,95 \%$ CI $1.06,1.62)$.

\section{LD evaluation and haplotype analysis}

rs1128334 was in strong LD with $\mathrm{rs} 12574073\left(r^{2}=0.95\right)$ (Figure 2). We identified eight different haplotypes in the studied population, but only three showed frequency $>3 \%$ (Table 2). As expected, the haplotype results were similar to the single-site association results, and haplotype TAT formed by rs12574073, rs1128334 and rs4937333 was strongly associated with increased risk of AS (OR 1.24, 95\% CI 1.05, 1.47, $P=0.01$ ), whereas haplotype CGC reduced the risk (OR 0.82, 95\% CI 0.70, 0.96, $P=0.01$ ).

\section{mRNA expression of ETS1 in peripheral blood} mononuclear cells (PBMCs)

We examined the mRNA levels of ETS1 in 50 AS patients and 161 healthy controls. Relative ETS1 mRNA expression was lower in cases than controls $(P<0.0001$, Figure 3).

\section{Allelic-specific expression of ETS1}

To determine whether rs1128334 was associated with ETS1 expression, we genotyped 161 healthy control samples for rs1128334 to compare the ETS1 expression in subjects with different genotypes of the SNP. ETS1 mRNA level was lower in AA $(\mathrm{n}=28)$ and AG $(\mathrm{n}=50)$ than GG $(\mathrm{n}=83)$ homozygotes $(P<0.01$, Figure 4$)$. Thus, carriers with the risk allele A of rs1128334 may exhibit significantly lower ETS1 mRNA expression than those with the allele G. In addition, analysis of healthy controls involved only rs1128334 and rs4937333 because of the high LD between rs12574073 and rs1128334 $\left(r^{2}=\right.$ 0.95 , Figure 2). Subjects carrying haplotype A-T $(\mathrm{n}=28)$ for rs1128334/rs4937333 had a significantly lower level of ETS1 than those carrying haplotype GC $(\mathrm{n}=69)(P<0.05$, Figure 5).

\section{Discussion}

We have demonstrated that ETS1 is associated with AS, thus adding to the list of loci showing overlap between AS, RA and SLE. We identified an SNP, rs1128334, located in the 3' UTR of ETS1, which was significantly associated with AS in Han Chinese people. We also showed a lower expression of ETS1 in peripheral leukocytes from patients than controls. Furthermore, the risk allele of rs1128334 and the risk haplotype A-T of rs1128334 and rs4937333 were significantly linked to decreased mRNA level of ETS1. To our knowledge, this is the first report demonstrating an association of ETS1 polymorphisms and AS in Han Chinese. Especially, we 
Table 1 Genotype and allele association analysis of seven single nucleotide polymorphisms (SNPs) in samples of AS in Shandong and rs1128334 in Ningxia

\begin{tabular}{|c|c|c|c|c|c|c|c|c|c|}
\hline Population & SNPs & Position & Genotype/allele & Patients, number (\%) & Controls, number (\%) & Odds ratio & $95 \% \mathrm{Cl}$ & $P$-value & $P^{*}$ \\
\hline & rs12574073 & 128319478 & CC & $423(42.7)$ & $401(47.8)$ & 1 & & & \\
\hline & & & $\mathrm{CT}$ & $457(46.1)$ & $356(41.8)$ & 1.217 & $1.002,1.478$ & 0.192 & \\
\hline & & & $\pi$ & $111(11.2)$ & $89(10.4)$ & 1.182 & $0.867,1.613$ & & \\
\hline & & & C & $1,303(65.7)$ & $1,170(68.7)$ & 1 & & & \\
\hline & & & $\mathrm{T}$ & $679(34.3)$ & $534(31.3)$ & 1.142 & $0.994,1.311$ & 0.062 & \\
\hline & rs1128334 & 128328959 & GG & $417(42.2)$ & $528(48.0)$ & 1 & & & \\
\hline & & & $A G$ & $457(46.3)$ & $471(42.8)$ & 1.229 & $1.024,1.473$ & 0.018 & \\
\hline & & & $\mathrm{AA}$ & $114(11.5)$ & $101(9.2)$ & 1.429 & $1.062,1.923$ & & \\
\hline & & & G & $1,291(65.3)$ & $1,527(69.4)$ & 1 & & & \\
\hline & & & A & $685(34.7)$ & $673(30.6)$ & 1.204 & $1.058,1.371$ & 0.005 & 0.035 \\
\hline & rs4937333 & 128330520 & $\pi$ & $183(18.2)$ & $177(15.6)$ & 1 & & & \\
\hline & & & $\mathrm{CT}$ & $483(48.0)$ & $535(42.3)$ & 0.873 & $0.687,1.111$ & 0.160 & \\
\hline & & & CC & $341(33.8)$ & $420(37.1)$ & 0.785 & $0.611,1.010$ & & \\
\hline & & & $\mathrm{T}$ & $849(42.2)$ & 889 (39.3) & 1 & & & \\
\hline & & & C & 1165 (57.8) & $1375(60.7)$ & 0.887 & $0.785,1.003$ & 0.057 & \\
\hline \multirow[t]{20}{*}{ Shandong } & rs4254089 & 128366221 & CC & $64(6.3)$ & $66(5.9)$ & 1 & & & \\
\hline & & & $\mathrm{CT}$ & $356(35.1)$ & 365 (32.9) & 1.006 & $0.692,1.461$ & 0.478 & \\
\hline & & & $\pi$ & 595 (58.6) & $680(61.2)$ & 0.902 & $0.629,1.295$ & & \\
\hline & & & C & $484(23.8)$ & $497(22.4)$ & 1 & & & \\
\hline & & & $\mathrm{T}$ & $1546(76.2)$ & 1725 (77.6) & 0.920 & $0.798,1.062$ & 0.259 & \\
\hline & rs7951925 & 128379964 & $\mathrm{AA}$ & $84(8.3)$ & $109(9.7)$ & 1 & & & \\
\hline & & & $A G$ & $420(41.4)$ & 444 (39.6) & 1.227 & $0.896,1.681$ & 0.433 & \\
\hline & & & GG & $510(50.3)$ & $569(51.7)$ & 1.163 & $0.854,1.584$ & & \\
\hline & & & A & $588(29.0)$ & $662(29.5)$ & 1 & & & \\
\hline & & & G & $1,440(71.0)$ & $1,582(70.5)$ & 1.025 & $0.898,1.169$ & 0.736 & \\
\hline & rs7116578 & 128388773 & AA & $869(85.9)$ & $970(86.3)$ & 1 & & & \\
\hline & & & $A G$ & $133(13.1)$ & 145 (12.9) & 1.024 & $0.795,1.318$ & 0.884 & \\
\hline & & & GG & $10(1.0)$ & $9(0.8)$ & 1.240 & $0.502,3.066$ & & \\
\hline & & & A & $1,871(92.4)$ & 2,085 & 1 & & & \\
\hline & & & G & 153 (7.6) & $163(7.3)$ & 1.046 & $0.832,1.316$ & 0.726 & \\
\hline & rs4937342 & 128398309 & $\pi$ & 903 (89.8) & $993(90.2)$ & 1 & & & \\
\hline & & & $\mathrm{TG}$ & $101(10.0)$ & $102(9.3)$ & 1.089 & $0.815,1.455$ & 0.368 & \\
\hline & & & GG & $2(0.2)$ & $6(0.5)$ & 0.367 & $0.074,1.821$ & & \\
\hline & & & $\mathrm{T}$ & 1,907 (94.8) & $2,088(94.8)$ & 1 & & & \\
\hline & & & G & $105(5.2)$ & $114(5.2)$ & 1.008 & $0.768,1.324$ & 1.000 & \\
\hline \multirow[t]{5}{*}{ Ningxia } & rs1128334 & 128328959 & GG & $135(38.4)$ & $190(47.5)$ & 1 & & & \\
\hline & & & $A G$ & $168(47.7)$ & $166(41.5)$ & 1.424 & $1.047,1.938$ & 0.038 & \\
\hline & & & AA & 49 (13.9) & $44(11.0)$ & 1.576 & $0.986,2.490$ & & \\
\hline & & & G & $438(62.2)$ & $546(68.2)$ & 1 & & & \\
\hline & & & A & $266(37.8)$ & $254(31.8)$ & 1.305 & $1.055,1.615$ & 0.015 & \\
\hline
\end{tabular}

*Adjusted $P$-value after Bonferroni correction. 


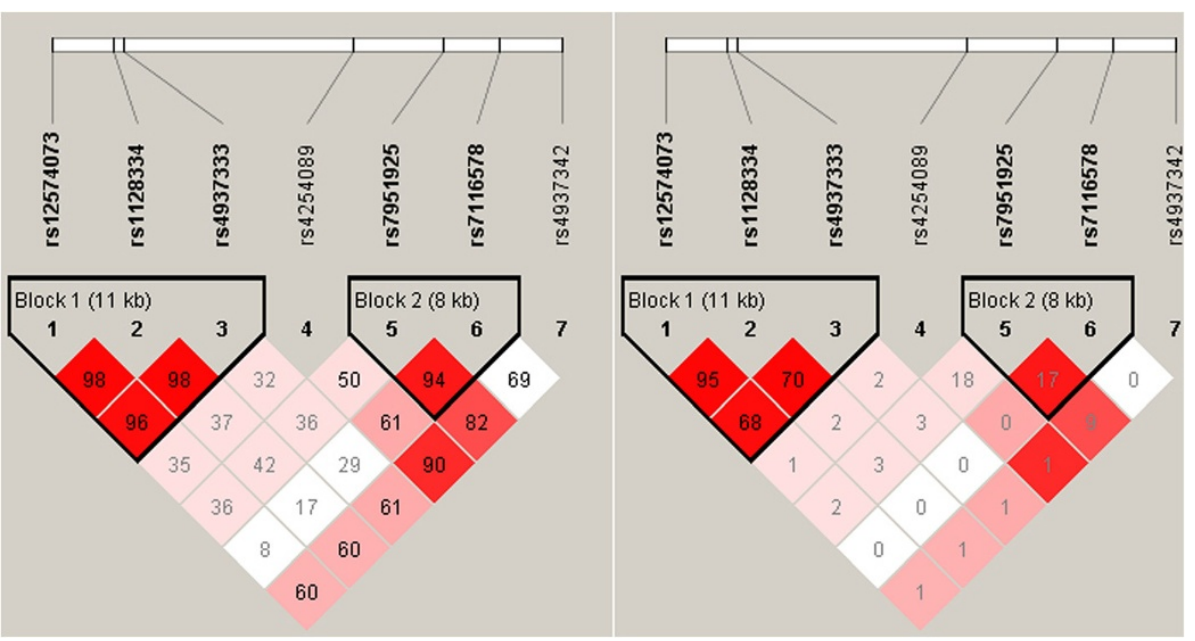

Figure 2 Linkage disequilibrium of seven single nucleotide polymorphisms (SNPs) in the ETS1 gene. Left, D'. Right, $r^{2}$.

verified the association of rs1128334 and AS in two populations, Han Chinese from Shandong and Ningxia, which enhances the credibility of our findings.

In previous reports, the common variants rs1128334, rs4937333 and rs6590330 were found to be significantly associated with SLE in east Asian populations. In addition, rs11221332 was suggested to be strongly associated with celiac disease in a European population and RA in a Caucasian population. In agreement with these studies of autoimmune diseases, we observed that ETS1 was also a susceptibility gene for AS at least in northern Han Chinese. Our findings provide support for many autoimmune diseases sharing the same susceptibility loci.

ETS1 encodes a member of the ETS family of transcription factors that activate transcription by binding to cis-regulatory elements in target genes $[19,20]$. The ETS1 transcription factor was initially discovered as the proto-oncogene corresponding to v-ets of the avian erythroblastosis virus (E26) [19,21], which harbors a conserved DNA-binding domain mediating specific DNA binding to the GGAA/T motif [20]. As a crucial transcription factor widely expressed in lymphocytes and vascular endothelial, lacteal glandular epithelium and various invasion tumor cells, ETS1 regulates the development, senescence and death of many immune cells $[22,23]$. It also plays a role in both innate and adaptive immune response $[23,24]$. Accumulating evidence points to an important role for ETS1 in regulating the differentiation of immune cells such as T-cell differentiation into a helper population, terminal differentiation of B cells, development of natural killer (NK) cells and NK T cells and the expression of cytokine and chemokine genes in a wide variety of different cell lineages [24-27]. Animal experiments showed that autoimmune disease developed in ETS1-knockout mice, as investigated by the production of high titers of autoantibodies, and immune cell infiltration into organs accounted for aberrations in lymphocyte differentiation [24].

In addition to roles in controlling the production of interferon-gamma in T helper (Th)1 cells [28] and driving normal Th2 cytokine production, ETS1 is also involved in the Th17 cell lineage as a negative regulator of Th17 cell differentiation [29]. Increasing studies suggest that Th17 cells are involved in the pathogenesis of AS [30]. Recently, Zhang et al. examined serum IL-17 levels from 283 SLE cases and observed a significant synergistic epistatic interaction between two risk variants, rs10893872 and rs1128334, in the ETS1 gene, and the haplotype formed by these variants was significantly associated with serum IL-17 levels in SLE patients [31], which supports a role for genetic interaction contributing to the complexity of autoimmune disease [31-33]. From our findings, subjects with AS carrying the risk allele A have significantly lower ETS1 expression than those

Table 2 Haplotype frequencies of three single nucleotide polymorphisms in all samples

\begin{tabular}{ccccc}
\hline Haplotype & No. (\%) of patients & No. (\%) of controls & Odds ratio (95\% Cl) & $P$-value \\
\hline T A T & $478.82(0.334)$ & $345.87(0.288)$ & $1.24(1.05,1.47)$ & 0.01 \\
C G C & $825.82(0.577)$ & $749.74(0.624)$ & $0.82(0.70,0.96)$ & 0.01 \\
C G T & $112.17(0.078)$ & $93.24(0.078)$ & $1.01(0.76,1.35)$ & 0.94 \\
\hline
\end{tabular}

The order of three SNPs: rs12574073, rs1128334, rs4937333. 


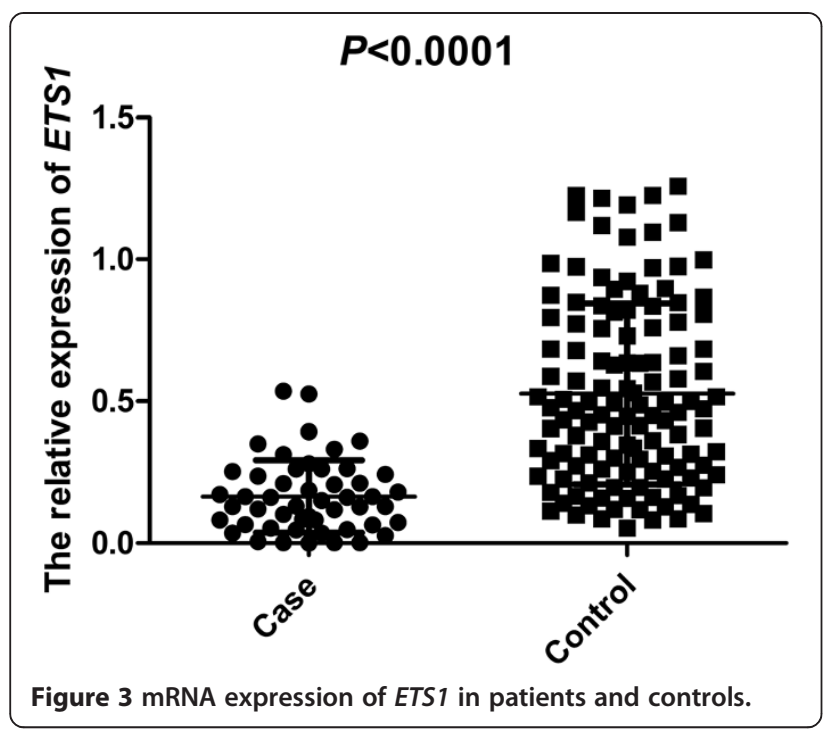

with the G allele. Similar to previous studies, the haplotype formed by rs12574073, rs1128334 and rs4937333 in ETS1 was significantly associated with AS susceptibility. As well, individuals carrying haplotype AT for rs1128334/rs4937333 showed less ETS1 expression than those carrying the GC haplotype. With the HCB data in HapMap, rs10893872 and rs4937333 are in perfect $\mathrm{LD}\left(r^{2}=1\right)$, so our results are consistent with the Zhang et al. study.

Much evidence has confirmed that microRNAs (miRNAs) can regulate gene expression by sequence-specific binding to target mRNAs, but the binding affinity can be affected by SNPs residing in miRNA target sites, which may in turn affect the ability of miRNA to inhibit the mRNA translation into proteins or lead to degradation of the mRNA [34]. Indeed, recent research has

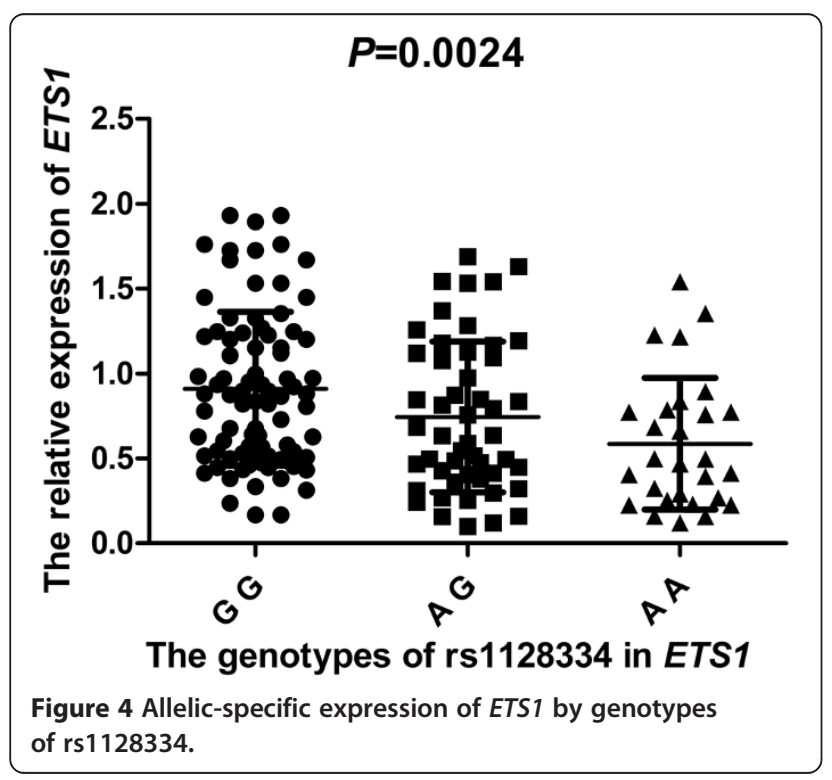

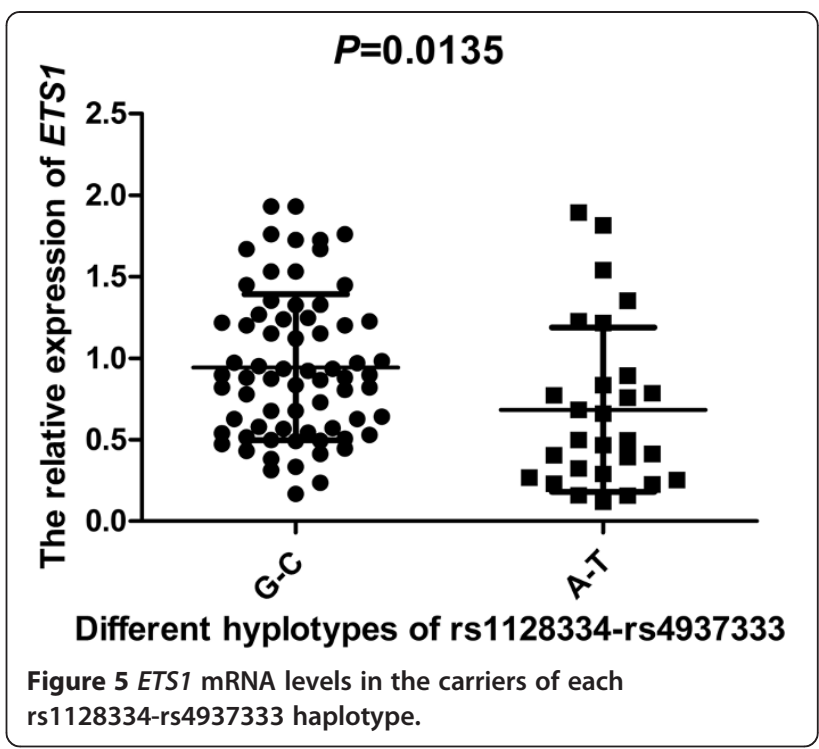

demonstrated that SNPs at miRNA binding sites likely affect the expression of the miRNA target genes and thus, may contribute to susceptibility to autoimmune diseases [35]. Therefore, we presumed that variants rs1128334 and rs4937333 located in the 3' UTR of ETS1 may affect miRNA binding affinity and further influence the expression of the target gene, which may contribute to susceptibility to AS. However, the detailed mechanism of this functional relationship requires further investigation.

\section{Conclusions}

In summary, our study identified that the common variants of ETS1 confer susceptibility to AS. This study might provide further evidence to improve our understanding of the exact function of ETS1 in the pathogenesis of autoimmune diseases.

\footnotetext{
Abbreviations

ANOVA: analysis of variance; AS: ankylosing spondylitis; bp: base pairs; Ct: threshold cycle; ERAP1: Endoplasmic reticulum aminopeptidase 1; ETS1: v-ets avian erythroblastosis virus E26 oncogene homolog 1;

GAPDH: glyceraldehydes-3-phosphate dehydrogenase; GWAS: genome-wide association study: CB: Han Chinese in Beijing: HLA: human leukocyte antigen; HWE: Hardy-Weinberg equilibrium; IL-17: interleukin 17; IL23R: interleukin 23 receptor; KIF21B: Kinesin family member 21B; LD: linkage disequilibrium; MHC: major histocompatibility complex; miRNA: microRNA; NK cell: natural killer cell; OR: odds ratio; PBMC: peripheral blood mononuclear cell; RA: theumatoid arthritis; RT-PCR: reverse transcription PCR; SLE: systemic lupus erythematosus; Th cell: T helper cell; UTR: untranslated region.
}

\section{Competing interests}

The authors declare that they have no competing interests.

\section{Authors' contributions}

SS: data collection and analysis, manuscript writing and final approval of the manuscript. JD: conception and design, critical revision and final approval of the manuscript. JL: conception and design, manuscript writing and final approval of the manuscript. ZY: data collection and analysis, critical revision and final approval of the manuscript. HZ: data collection and analysis, critical revision and final approval of the manuscript. QX: data collection and analysis, critical revision and final approval of the manuscript. XM: 
conception and design, critical revision and final approval of manuscript. YL: data collection and analysis, manuscript writing and final approval of the manuscript. XB: data collection and analysis, critical revision and final approval of the manuscript. YG: conception and design, critical revision and final approval of the manuscript. QL: conception and design, data collection and analysis, manuscript writing, final approval of the manuscript. All authors read and approved the final manuscript.

\section{Acknowledgements}

We thank all the participants in the study. This work was supported by grants from the Natural Science Foundation of China (81072452, 81273281) and the Ph.D. Programs Foundation of the Ministry of Education of China (20100131110035)

\section{Author details}

${ }^{1}$ Key Laboratory for Experimental Teratology of the Ministry of Education and Department of Medical Genetics, Shandong University School of Medicine, Jinan, Shandong 250012, China. ${ }^{2}$ Department of Medical Genetics and Cell Biology, Ningxia Medical University, Yinchuan, Ningxia 750004, China. ${ }^{3}$ Institute of Geriatrics, Beijing Hospital, Ministry of Health of PR China, Beijing 100730, China

Received: 24 January 2014 Accepted: 25 March 2014

Published: 4 April 2014

\section{References}

1. Braun J, Sieper J: Ankylosing spondylitis. Lancet 2007, 369:1379-1390

2. van der Heijde D, Calin A, Dougados M, Khan MA, van der Linden S, Bellamy N: Selection of instruments in the core set for DC-ART, SMARD, physical therapy, and clinical record keeping in ankylosing spondylitis, Progress report of the ASAS Working Group. Assessments in Ankylosing Spondylitis. J Rheumatol 1999, 26:951-954.

3. Braun J, Bollow M, Remlinger G, Eggens U, Rudwaleit M, Distler A, Sieper J: Prevalence of spondylarthropathies in HLA-B27 positive and negative blood donors. Arthritis Rheum 1998, 41:58-67.

4. Brown MA, Kennedy LG, MacGregor AJ, Darke C, Duncan E, Shatford JL, Taylor A, Calin A, Wordsworth P: Susceptibility to ankylosing spondylitis in twins: the role of genes, HLA, and the environment. Arthritis Rheum 1997, 40:1823-1828.

5. Reveille JD: The genetic basis of spondyloarthritis. Ann Rheum Dis 2011, 70:44-50.

6. Danoy P, Pryce K, Hadler J, Bradbury LA, Farrar C, Pointon J, Ward M, Weisman M, Reveille JD, Wordsworth BP, Stone MA, Maksymowych WP, Rahman P, Gladman D, Inman RD, Brown MA: Association of variants at $1 \mathrm{q} 32$ and STAT3 with ankylosing spondylitis suggests genetic overlap with Crohn's disease. PLoS Genet 2010, 6:e1001195.

7. Burton PR, Clayton DG, Cardon LR, Craddock N, Deloukas P, Duncanson A, Kwiatkowski DP, McCarthy MI, Ouwehand WH, Samani NJ, Todd JA, Donnelly P, Barrett JC, Davison D, Easton D, Evans DM, Leung HT, Marchini $J$, Morris AP, Spencer CC, Tobin MD, Attwood AP, Boorman JP, Cant B, Everson U, Hussey JM, Jolley JD, Knight AS, Koch K, Meech E, et al: Association scan of 14,500 nonsynonymous SNPs in four diseases identifies autoimmunity variants. Nat Genet 2007, 39:1329-1337.

8. Yang W, Shen N, Ye DQ, Liu Q, Zhang Y, Qian XX, Hirankarn N, Ying D, Pan HF, Mok CC, Chan TM, Wong RW, Lee KW, Mok MY, Wong SN, Leung AM, Li $X P$, Avihingsanon Y, Wong CM, Lee TL, Ho MH, Lee PP, Chang YK, Li PH, Li RJ, Zhang L, Wong WH, Ng IO, Lau CS, Sham PC, et al: Genome-wide association study in Asian populations identifies variants in ETS1 and WDFY4 associated with systemic lupus erythematosus. PLOS Genet 2010, 6:e1000841.

9. Han JW, Zheng HF, Cui Y, Sun LD, Ye DQ, Hu Z, Xu JH, Cai ZM, Huang W, Zhao GP, Xie HF, Fang H, Lu QJ, Li XP, Pan YF, Deng DQ, Zeng FQ, Ye ZZ, Zhang XY, Wang QW, Hao F, Ma L, Zuo XB, Zhou FS, Du WH, Cheng YL, Yang JQ, Shen SK, Li J, Sheng YJ: Genome-wide association study in a Chinese Han population identifies nine new susceptibility loci for systemic lupus erythematosus. Nat Genet 2009, 41:1234-1237.

10. Chatzikyriakidou A, Voulgari PV, Georgiou I, Drosos AA: Altered sequence of the ETS1 transcription factor may predispose to rheumatoid arthritis susceptibility. Scand J Rheumatol 2013, 42:11-14.

11. Dubois PC, Trynka G, Franke L, Hunt KA, Romanos J, Curtotti A, Zhernakova A, Heap GA, Adany R, Aromaa A, Bardella MT, vanden Berg LH, Bockett NA dela Concha EG, Dema B, Fehrmann RS, Fernandez-Arquero M, Fiatal S, Grandone E, Green PM, Groen HJ, Gwillian R, Houwen RH, Hunt SE, Kaukinen K, Kelleher D, Korponay-Szabo I, Kurppa K, MacMathuna P, Maki M, et al: Multiple common variants for celiac disease influencing immune gene expression. Nat Genet 2010, 42:295-302.

12. Richard-Miceli C, Criswell LA: Emerging patterns of genetic overlap across autoimmune disorders. Genome Med 2012, 4:6.

13. Liu Y, Zhang H, Li J, Zhao H, Xin Q, Shan S, Dang J, Bian X, Liu Q: Association of common variants in KIF21B and ankylosing spondylitis in a Chinese Han population: a replication study. Immunogenetics 2013, 65:835-839.

14. Chen J, Zhou L, Huo ZH, Zhang YH, Yang ZH, Yang BZ, Huang CB, Zhu XQ Yang Z: Identification of a novel lymphotoxin-alpha (LTA) gene associated with ankylosing spondylitis in Ningxia population. Yi Chuan 2011, 33:329-336.

15. The data about the minor allele frequency of all SNPs for Han Chinese in Beijing (HCB) in HapMap. [www.hapmap.org]

16. Zhao H, Yang W, Qiu R, Li J, Xin Q, Wang X, Feng Y, Shan S, Liu Y, Gong Y, Liu Q: An intronic variant associated with systemic lupus erythematosus changes the binding affinity of Yinyang1 to downregulate WDFY4. Genes Immun 2012, 13:536-542.

17. Comparison of the allele frequency of the 7 SNPs for patients and controls involved Fisher's exact test using Plink 1.07 online. [http://pngu.mgh.harvard.edu/ purcell/plink/]

18. Shi YY, He L: SHEsis, a powerful software platform for analyses of linkage disequilibrium, haplotype construction, and genetic association at polymorphism loci. Cell Res 2005, 15:97-98.

19. Leprince D, Gegonne A, Coll J, de Taisne C, Schneeberger A, Lagrou C, Stehelin D: A putative second cell-derived oncogene of the avian leukaemia retrovirus E26. Nature 1983, 306:395-397.

20. Wang CY, Petryniak B, Ho IC, Thompson CB, Leiden JM: Evolutionarily conserved Ets family members display distinct DNA binding specificities. J Exp Med 1992, 175:1391-1399.

21. Nunn MF, Seeburg PH, Moscovici C, Duesberg PH: Tripartite structure of the avian erythroblastosis virus E26 transforming gene. Nature 1983, 306:391-395.

22. Du J, Shen L, Zhao GH, Wang YG, Liao SS, Chen C, Zhou ZF, Luo YY, Jiang $\mathrm{H}$, Xia K, Tang BS: Receptor expression-enhancing protein 1 gene (SPG31) mutations are rare in Chinese Han patients with hereditary spastic paraplegia. Chin Med J (Engl) 2009, 122:2064-2066.

23. Gallant $\mathrm{S}$, Gilkeson G: ETS transcription factors and regulation of immunity. Arch Immunol Ther Exp (Warsz) 2006, 54:149-163.

24. Russell L, Garrett-Sinha LA: Transcription factor Ets-1 in cytokine and chemokine gene regulation. Cytokine 2010, 51:217-226.

25. Maier H, Colbert J, Fitzsimmons D, Clark DR, Hagman J: Activation of the early B-cell-specific mb-1 (Ig-alpha) gene by Pax-5 is dependent on an unmethylated Ets binding site. Mol Cell Biol 2003, 23:1946-1960.

26. Garvie CW, Hagman J, Wolberger C: Structural studies of Ets-1/Pax5 complex formation on DNA. Mol Cell 2001, 8:1267-1276.

27. Pufall MA, Graves BJ: Ets-1 flips for new partner Pax-5. Structure 2002, 10:11-14

28. Nagaleekar VK, Diehl SA, Juncadella I, Charland C, Muthusamy N, Eaton S, Haynes L, Garrett-Sinha LA, Anguita J, Rincon M: IP3 receptor-mediated $\mathrm{Ca} 2+$ release in naive CD4 T cells dictates their cytokine program. J Immunol 2008, 181:8315-8322.

29. Moisan J, Grenningloh R, Bettelli E, Oukka M, Ho IC: Ets-1 is a negative regulator of Th17 differentiation. J Exp Med 2007, 204:2825-2835.

30. Shen H, Goodall JC, Hill Gaston JS: Frequency and phenotype of peripheral blood Th17 cells in ankylosing spondylitis and rheumatoid arthritis. Arthritis Rheum 2009, 60:1647-1656

31. Zhang J, Zhang Y, Zhang L, Yang J, Ying D, Zeng S, Lee TL, Lau CS, Chan TM, Leung AM, Mok CC, Wong SN, Lee KW, Ho MH, Lee PP, Chung BH, Chong CY, Wong RW, Mok MY, Wong WH, Lau YL, Yang W: Epistatic interaction between genetic variants in susceptibility gene ETS1 correlates with IL-17 levels in SLE patients. Ann Hum Genet 2013, 77:344-350.

32. Hughes T, Adler A, Kelly JA, Kaufman KM, Williams AH, Langefeld CD, Brown EE, Alarcon GS, Kimberly RP, Edberg JC, Ramsey-Goldman R, Petri M, Boackle SA, Stevens AM, Reveille JD, Sanchez E, Martin J, Niewold TB, Vila LM, Scofield RH, Gilkeson GS, Gaffney PM, Criswell LA, Moser KL, Merrill JT, Jacob CO, Tsao BP, James JA, Vyse TJ, Alarcon-Riquelme ME, et al: Evidence for 
gene-gene epistatic interactions among susceptibility loci for systemic lupus erythematosus. Arthritis Rheum 2011, 64:485-492.

33. Zhou XJ, Lu XL, Nath SK, Lv JC, Zhu SN, Yang HZ, Qin LX, Zhao MH, Su Y Shen N, Li ZG, Zhang H: Gene-gene interaction of BLK, TNFSF4, TRAF1, TNFAIP3, and REL in systemic lupus erythematosus. Arthritis Rheum 2011, 64:222-231.

34. Wei JC, Yen JH, Juo SH, Chen WC, Wang YS, Chiu YC, Hsieh TJ, Guo YC, Huang $\mathrm{CH}$, Wong RH, Wang HP, Tsai KL, Wu YC, Chang HW, Hsi E, Chang WP, Chang WC: Association of ORAl1 haplotypes with the risk of HLA-B27 positive ankylosing spondylitis. PLoS One 2011, 6:e20426.

35. Hikami K, Kawasaki A, Ito I, Koga M, Ito S, Hayashi T, Matsumoto I, Tsutsumi A, Kusaoi M, Takasaki Y, Hashimoto H, Arinami T, Sumida T, Tsuchiya N: Association of a functional polymorphism in the 3 '-untranslated region of SPI1 with systemic lupus erythematosus. Arthritis Rheum 2011, 63:755-763.

doi:10.1186/ar4530

Cite this article as: Shan et al.: ETS1 variants confer susceptibility to ankylosing spondylitis in Han Chinese. Arthritis Research \& Therapy 2014 16:R87.

\section{Submit your next manuscript to BioMed Central and take full advantage of:}

- Convenient online submission

- Thorough peer review

- No space constraints or color figure charges

- Immediate publication on acceptance

- Inclusion in PubMed, CAS, Scopus and Google Scholar

- Research which is freely available for redistribution 